\title{
"Hårt arbete har gjort mig till den jag är"- pengar och moraliskt värde som pedagogiska aspekter i två Kalle Anka-album
}

\author{
Lars Wallner \\ Linköpings universitet
}

\begin{abstract}
Sammanfattning
Kalle Anka \& Co har hyllats för sitt berättande och sina karaktärer, samtidigt som serien kritiserats för att vara förmedlare av kulturimperialism. Denna artikel diskuterar två seriealbum skapade för användning i svensk grundskola, sammansättningar av tidigare publicerade serier. Då dessa samlingar är tänkta att användas i skola så kan samlingarna också förväntas gestalta värderingar i linje med detta. Som centrum för handlingen, eller för karaktärsmotivation, är pengar den enskilt mest förekommande faktorn i dessa berättelser. Nio berättelser har valts ut och analyseras utifrån 1) hur fattiga och rika karaktärer porträtteras genom bild och text och 2) hur pengar och materialism konstrueras som moraliska värden. Analysen visar hur värden om materialism och pengar representeras av olika karaktärer: Joakim von Anka (rikedom, snålhet), Kalle Anka (lättja, slösaktighet) och Knattarna (godhet, arbetsiver). Som representanter för barnläsaren skildras Knattarna som goda arbetare, där arbetet är sin egen belöning och essentiellt för god karaktär. Dock kan rikedom som kommer från hårt arbete (till exempel Joakims) associeras med omoral om inte pengarna används till goda syften. Vidare gestaltas vissa karaktärer som intrinsikalt fattiga, vilket kan ses som problematiskt om det inte diskuteras tillsammans med unga läsare. Här kan läraren vara avgörande för elevers möjlighet till texttolkning.
\end{abstract}

Nyckelord: Disney; kognitiv narratologi; materialism; serietidningar; värderingar

\begin{abstract}
"Hard work made me who I am"- money and moral value as pedagogical aspects of two Donald Duck albums

Donald Duck \& Co have been simultaneously celebrated for vivid stories and characters, and criticized as being conveyors of cultural imperialism. This article discusses two comic albums collecting previously published comics for use in Swedish elementary school. As these collections are designed for schools, they can be expected to impart certain school values. As plot device, or as basis for character motivation, money is the single most common factor in a majority of the stories. Therefore, nine stories have been analysed, focusing primarily on 1) character portrayal through image and text, and 2) how money and materialism are constructed as moral values. The
\end{abstract}

^Korrespondanse: Lars Wallner, epost: lars.wallner@liu.se

(C) 2020 Lars Wallner. This is an Open Access article distributed under the terms of the Creative Commons Attribution 4.0 International License (https://creativecommons.org/licenses/by-nc/4.0/), allowing third parties to copy and redistribute the material in any medium or format and to remix, transform, and build upon the material for any purpose, even commercially, provided the original work is properly cited and states its license.

Citation: L. Wallner. "'Hårt arbete har gjort mig till den jag är"-pengar och moraliskt värde som pedagogiska aspekter i två Kalle Anka-album" Nordic Fournal of Literacy Research, Vol. 6(2), 2020, pp. 59-73. http://dx.doi.org/10.23865/njlr.v6.1820 


\section{Wallner}

analysis shows how values of materialism and money are displayed differently, represented by different characters: Scrooge McDuck (wealth, greed), Donald Duck (sloth, wastefulness), and Huey, Dewey and Louie (goodness, hard-working). As representatives of the child reader, the nephews show a love of hard work essential to good moral character. However, wealth that comes from hard work (Scrooge's wealth) could also be immoral if it is not spent properly (or at all). Moreover, certain characters are constructed as intrinsically poor and hopeless, which is problematic. Here, the teacher could be vital for students' possibilities of interpreting the texts.

Keywords: Cognitive narratology; comics; Disney; materialism; values

Responsible editor: Atle Skaftun

Received: August, 2019; Accepted: June, 2020; Published: October, 2020

Kalle Anka \& CO är en av världens mest kända serietidningar. Den har hyllats för sin kreativitet och konstnärlighet samtidigt som den anklagats för att vara förmedlare av amerikansk kulturimperialism (Dorfman \& Mattelart, 1991) och kommersialism (Knutsson, 1986). De flesta läsare av Kalle Anka är väl medvetna om den roll som pengar spelar i serien, oavsett om det är Farbror Joakims jakt på nya förmögenheter eller försvar av sin pengabinge, Kalle Ankas ständiga skiften av jobb och problem med vardagsekonomin eller Björnligans brottsliga eskapader för att stjäla till sig rikedomar. I denna artikel analyseras och diskuteras hur pengar och rikedom är narrativa aspekter som kan knytas till moraliska värden.

Debatten om serietidningens moral är inget nytt och knappast avslutad (se till exempel Knutsson, 2018), men trots detta fortsätter serier att vara ett populärt läsmaterial bland barn och unga (Skolverket, 2017), som bland annat används i skolan (se till exempel Tilley \& Weiner, 2017; Wallner, 2017). 2012-2013 publicerade Egmont Publishing två seriealbum (Carlsson, 2012, 2013) samt ett arbetsmaterial för att använda dessa serier i skolan (Egmont Publishing, 2019a). I albumen har de samlat och återpublicerat en rad berättelser, och publikationen av och den didaktiska intentionen med dessa två album ger en möjlighet att analysera inte bara en allmän utgivning av Kalle Anka \& Co, utan berättelser specifikt samlade för att användas med barnläsare $i$ en pedagogisk kontext - där förmedlande av värderingar är något centralt. Vilka värden skapas i Kalle Anka-berättelserna, och hur förmedlas de till barnläsaren?

\section{Syfte}

Syftet med denna artikel är att belysa och diskutera hur Kalle Anka-serier konstruerar pengar, ekonomi och materialism som relaterat till moraliska värden, och hur läsningen av dessa värden är relevant i en pedagogisk kontext. Detta görs genom att undersöka två Kalle Anka-album som satts ihop för användning i pedagogiskt syfte. Dessa analyseras utifrån två huvudsakliga frågor: 
1) hur fattiga och rika karaktärer porträtteras i serierna genom bild och text, och

2) hur dessa karaktärers handlingar kan läsas som uttryck av moraliska värden.

\section{Metod}

Denna artikel diskuterar två seriealbum, Kalle Anka och hans vänner (Carlsson, 2013) och Välkommen till Ankeborg (Carlsson, 2012). Dessa publicerades för användning i årskurs 3-4 i samband med projektet Serier $i$ undervisningen (se Egmont Publishing $2019 b$ ), vars primära syfte är att främja läsning. Albumen samlar totalt 22 berättelser tidigare publicerade av Disney mellan 1934 och 2012, och denna artikel har analyserat fyra av dessa berättelser där pengar är en drivande faktor i handlingen eller för någon specifik karaktär. Historier som valts bort handlar istället till exempel om att upptäcka hur en specifik uppfinning fungerar eller hantera klassens mobbare. De utvalda texterna inkluderar en rad olika återkommande karaktärer i Ankeborg där Joakim von Anka, Kalle och Knattarna är de vanligast förekommande - därför har dessa även valts ut som fokus för denna analys. Även andra karaktärer - Björnligan, Alexander Lukas, Farmor Anka - skulle kunna användas i en liknande analys (för en diskussion av dessa karaktärers roll, se till exempel Ørvad Andersen et al., 1974). Serierna har lästs med fokus på hur pengar och materialitet skildras i textuell dialog såväl som i bilder av karaktärer och miljö. Ämnet pengar och materialitet har valts av två huvudsakliga anledningar: dels för att pengar var den enskilt vanligaste motivationen för huvudkaraktärers såväl som antagonisters handlingar, vilket gör det till en viktig faktor för handlingen i serierna, och dels för att ekonomisk status och materiell välfärd presenteras som huvuddragen hos flertalet av huvudkaraktärerna i Kalle Anka \& Co, där Joakim von Anka är en av de mest framstående. Då ekonomi, materialitet, pengar och hållbarhet är återkommande begrepp i skolans värld (till exempel Skolverket, 2019, s. 24, 42, 227) är det relevant att undersöka hur dessa album illustrerar dessa frågor.

\section{Värden och konsumtion i barns läsning}

Serietidningen "måste ses som en av flera faktorer i utvecklingen av materiella värden, och som både en bidragande del till, och en reflektion av, dessa värden” (Belk, 1987, s. 26). Även om det kan ifrågasättas huruvida serier som Kalle Anka har något kulturellt värde i sig, så kan de ändå undersökas utifrån hur kulturella och sociala värden kan skapas genom läsningen av dem. Som tidigare exempel på detta har Lindgren (2000) undersökt Kalle Anka som förmedlare av värden om barnuppfostran, något som tidningarna kritiserades för under 1970-talet. Lindgren visar hur serien kan läsas som ett progressivt inspel på barnuppfostran där Kalles papparoll låter Knattarna få eget ansvar och frihet. Knutsson (1986, s. 28) demonstrerar på liknande sätt hur Kalle Anka kan läsas som mer än "bärare av en renodlat kapitalistisk ideologi", utan även som mångfacetterade, betydelsebärande verk. 


\section{Wallner}

Barndom och konsumtion har kommit att bli tätt förknippade, och detta hör också ihop med värden och normer i barnkulturen (Sparrman \& Sandin, 2012; Woolgar, 2012). Om vi betraktar produktionen av dessa värden som kontextuellt och kulturellt situerad i lästillfället, så är det relevant att undersöka de värden som produceras i de två aktuella albumen - utifrån deras syfte att användas i skolan - en plats där barns värdegrund etableras i unga år (se till exempel Skolverket, 2019). Som Herman och Vervaeck (2007, s. 219) skriver så finns det "ingen perfekt rekonstruktion av en texts ideologi, eftersom den alltid är informerad av läsarens ideologi”, så läsningen av dessa texter, och värden däri, kan naturligtvis skifta.

\section{Ett kognitivt narratologiskt perspektiv}

Analysen i denna artikel utgår ifrån en teoretisk kognitiv narratologi och utforskar hur texterna "genom sin berättartekniska uppbyggnad tilltalar läsare kognitivt och känslomässigt" (Nikolajeva, 2017, s. 49). Här studeras inte receptionen av materialet, utan en teoretisk textanalys görs. Detta är ett kvalitativt perspektiv för att förstå seriekaraktärerna "som idébärare eller språkrör för ideologier och övertygelser, som mönsterbilder för unga läsare" (Nikolajeva, 2017, s. 147). På detta sätt analyseras hur läsaren kan associera till ett övergripande schema (se till exempel Bordwell, 1991; Kukkonen, 2013) av materialism, pengar och moral. Som fiktion står serietidningen ut genom det sätt på vilket läsaren följer specifika karaktärer och deras öden och äventyr, snarare än att en specifik berättelse är i fokus. Fiktiva karaktärer komponeras "based in norms of social personhood" (Frow, 2018, s. 113) och vi läser dem som innehavare av sociala värden. Utifrån karaktärers ethos, deras moral, kan vi förstå dem som innehavare av dygder och brister (Frow, 2018).

Texterna har analyserats för att förstå hur pengar och rikedom sätts i relation till moraliska värden, och hur detta kan förstås av läsaren. Serierna har lästs i sökandet efter

elements on the page that prompt readers to draw particular inferences which, in turn, can be based on our cultural knowledge or psychological capacities ... how the story engages readers' everyday cognitive capacities for making sense of the world. (Kukkonen, 2013, s. 13)

Läsaren associerar (eng.: draw inferences) till kognitiva scheman som guidar förståelsen av texten (Kukkonen, 2013). Dessa scheman är inte deterministiska utan en hjälp för oss att förstå, men vår vana vid vissa typer av scheman påverkar också vår förmåga att läsa nya berättelser - information som inte passar in i schemat tenderar att förtryckas (Kukkonen, 2013). Kintsch (1998, s. 95) ger exemplet: "The car drove over the bridge", och menar att läsaren i detta fall troligare associerar till vattendrag snarare än kortspel. Detta perspektiv används i denna artikel för att se vilka associationer som kan göras av en tilltänkt läsare utifrån den visuella och textuella information som ges. 
I artikeln redovisas i huvudsak exempel från fyra texter: "Ståtliga statyer" (Barks, 2013[1952]), "Pengaregn" (Barks, 2013[1951]), "Snålheten bedrar visheten" (Troelstrup \& Santanach, 2012[2006]) och "Jul i Pengalösa” (Barks, 2013[1952]), även om även andra texter i antologierna också berörs. Texterna läses inte utifrån den historiska eller sociala kontext då de skapades - huruvida till exempel Barks ritade serier med kulturella koder för en publik på femtiotalet är irrelevant för dagens läsning av serierna, utan det som är intressant är vilka associationer som kan göras utifrån dem och vilka scheman som kan relateras till.

\section{Farbror Joakim - antagonist, protagonist och moralisk ledstjärna?}

I "Ståtliga statyer" tävlar Farbror Joakim och Maharadjan av Kovostan om att bygga den större, och mer kostsamma, statyn av Ankeborgs grundare Cornelius Knös. Joakim är initialt ointresserad av att bidra till någon staty, men när Maharadjan donerar pengar och beskrivs som den rikaste mannen i världen, väcks Joakims tävlingslust.

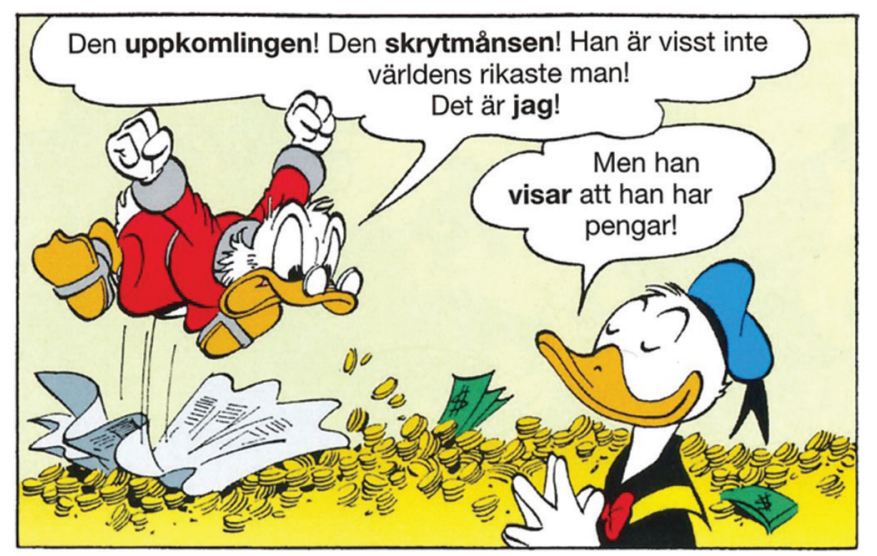

Figur 1. Barnslig snikenhet (Barks, 2012[1952], s. 78). Reproducerad med tillstånd av Egmont Publishing (C) Disney.

Kalle och hans farbror befinner sig på kontoret i pengabingen, som är så full att pengarna flödar ut även där. I många paneler syns den traditionella pengapåsen med dollartecken, och gestaltandet av kontanter på det här sättet är en förenklad syn på pengar typisk för serien och något som kan kontrasteras till dagens allt mer kontantlösa verklighet (se till exempel Kalka, 2009). Joakims gestikulerande, minspel och repliker signalerar samtliga upprördhet över att en "struntmiljardär kommer hit och gör sej viktig!" (Barks, 2012[1952], s. 79). I figur 1 hoppar Joakim fysiskt upp och ner på denna nyhet (som han läst i tidningen) som ett upprört barn skulle göra. Hans barnsliga utspel kontrasteras av Kalle som, med ett harmoniskt lugn i ansiktet och händerna ihop i en nästan meditativ pose, poängterar att det är viktigt att visa sin rikedom för andra, något Joakim finner skrytsamt. 


\section{Wallner}

En tävling utbryter då Maharadjan skänker hundratusen kronor till att bygga en staty, men då för att det är en struntsumma, inte på grund av någon uttalad god vilja. När folkmassan hyllar Maharadjan så är det heller inte för hans godhet gentemot staden utan för hans pengar, vilket visar allmänhetens uppskattning av skådespelet. När de båda rikemännen spenderar allt mer på nya och större statyer spekulerar folket över att de båda ska ruinera sig - en tydligt uttryckt skadeglädje som även tar sig uttryck när de tror att Joakim misslyckats (Figur 2).

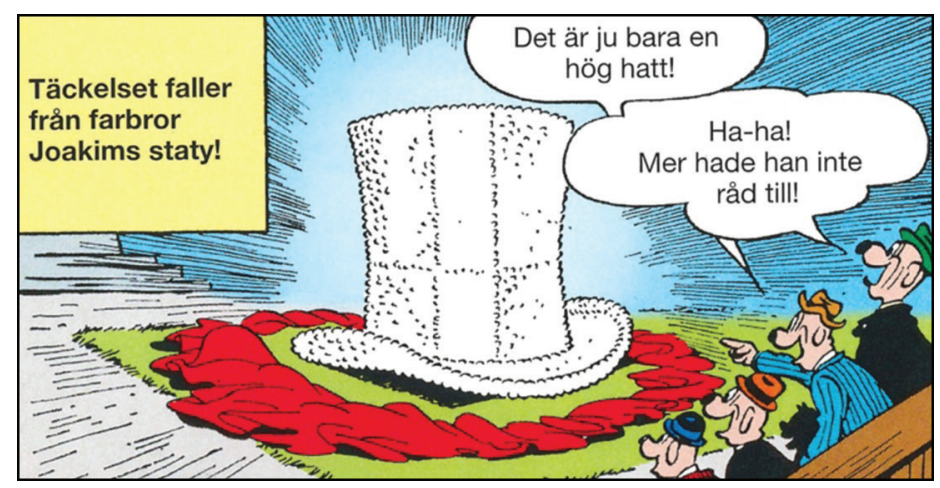

Figur 2. Folkets skadeglädje över vad de tror är Joakims misslyckande (Barks, 2012[1952], s. 84). Reproducerad med tillstånd av Egmont Publishing (C) Disney.

Möjligheten att männen skulle kunna förlora sina förmögenheter är här alltså viktigare än det resursslöseri, eller någon eventuell nytta, deras pengar skulle kunna göra istället. I slutändan ser de två miljardärerna också ut att ha ruinerat sig på statyer och Maharadjan är mycket riktigt utblottad. Det visar sig dock att Joakim bara har tömt sitt valv med "småpengar" (Barks, 2012[1952], s. 85), och fortfarande har sina tre kubiktunnland med pengar kvar i källaren.

Kalles uppmaning att Joakim ska visa sina pengar kommer också att utgöra grundschemat för historien: sinneslöst slöseri straffar sig. De rika männens barnsliga slöseri med pengar är ett skådespel för allmänheten, där läsaren ur Kalles och Knattarnas perspektiv får skåda hur de båda miljardärerna går till allt större överdrift. Slöseri och skryt presenteras alltså som något värdenegativt. Farbror Joakim moraliserar tidigt om att han inte slösar med pengar (det är naturligtvis också ett återkommande drag hos karaktären), därav kan läsaren förvånas över det fantasieggande slöseriet i denna berättelse. Bara genom tävlingsmomentet skapas en kontrast här mellan Farbror Joakims och Maharadjans slöseri - den senare är tveklöst antagonisten (vi följer berättelsen ur ankornas perspektiv, och Maharadjan hotar Joakims position), även om hans karaktärsdrag på många sätt påminner om Joakims. Han är också den som förlorar striden om rikaste man, och när hans pengar är slut behandlas han lika illa som han själv behandlat andra, han får tigga, borgmästaren tar hans kläder och hans anställda lämnar honom (Figur 3). I figur 3 visas fyra olika ansiktsuttryck hos tre karaktärer, 
som kan representera resultatet av slöseriet: trötthet och rädsla (Maharadjan), avsky (skattmästaren) och ilska (Borgmästaren). Borgmästaren, som bilderna tidigare visat som oroligt vädjande och krälande för att få slöseriet att sluta, är nu istället rakryggat barsk när Maharadjan inte längre har sin ekonomiska status och trygghet.
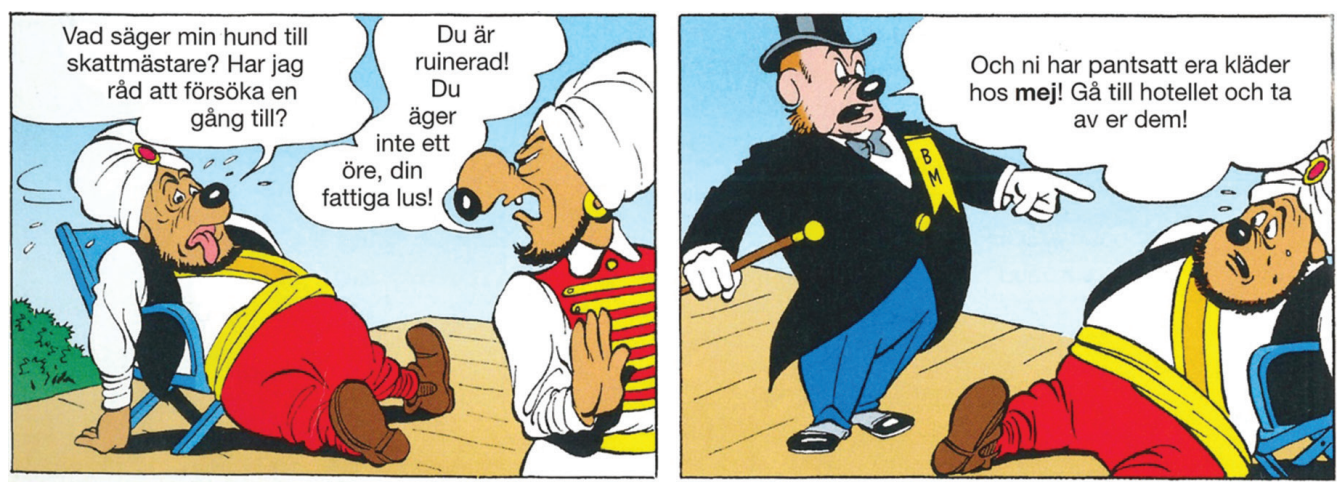

Figur 3. När Maharadjan är fattig har han inga allierade kvar (Barks, 2012[1952], s. 84). Reproducerad med tillstånd av Egmont Publishing (C) Disney.

Farbror Joakim, å andra sidan, går vinnande ur striden då det visar sig att han inte slösat bort alla sina pengar. Kalle och Knattarna har flertalet gånger i berättelsen oroat sig för att Joakims pengar ska ta slut, vilket indikerat för läsaren att detta är ett reellt hot. Hans kassavalv ser $u t$ att vara tomt, vilket både läsaren och Maharadjan tolkar som att han är utfattig (något Maharadjan också påpekar skadeglatt). Joakims vinnande kort blir dock att hans enorma tillgångar är till synes oändliga. Där Maharadjan har slösat bort alla sina pengar, har Joakim varit mer återhållsam. Hans sparande och snålande - grunden i hans ekonomiska moral - lönar sig.

En rad antagonister finns representerade i dessa berättelser, till exempel Joakim von Anka, Maharadjan och Björnligan. Joakim skiljer sig från övriga då han sedan 1950talet omformats från den antagonist han var från början till en godhjärtad snåljåp som hederligt kämpat sig till sin rikedom (Barrier, 2014). De andra antagonisterna i Kalle Anka visar exempel på skurkaktighet som en omoralisk vilja till oförtjänt rikedom Björnligan är det största hotet mot Joakim då hans arbetsetik speglas i deras lika hårda arbete för att stjäla hans pengar (Barrier, 2014; Kalka, 2009). Joakim råkar också illa ut på grund av själviskt, omoraliskt beteende, dock så skiljer sig detta från de 'riktiga' skurkarna - Joakims omoral förklaras med hans snålhet, och han gör ofta rätt i slutändan. Skurkarna används som perspektiv på Joakims girighet och gör det lättare för läsaren att sympatisera med Joakim trots hans brister. Det finns gränser som han inte är beredd att stiga över. I "Berg i fara" (Barks \& Jippes, 2013 [1972]) bryter han kol från ett berg där Gröngölingarna befinner sig. När Knattarna upplyser honom om detta kallar han Gröngölingarna "naturnötter" och "tröttsamma typer!" (Barks \& Jippes, 2013 [1972], s. 53), men när han tappar kontrollen över kolgrävningsmaskinen, och den hotar att 
rasera berget, visar hans ansiktsuttryck tydlig oro, även om texten i pratbubblorna i sig inte nödvändigtvis uttrycker samma sak (Figur 4).
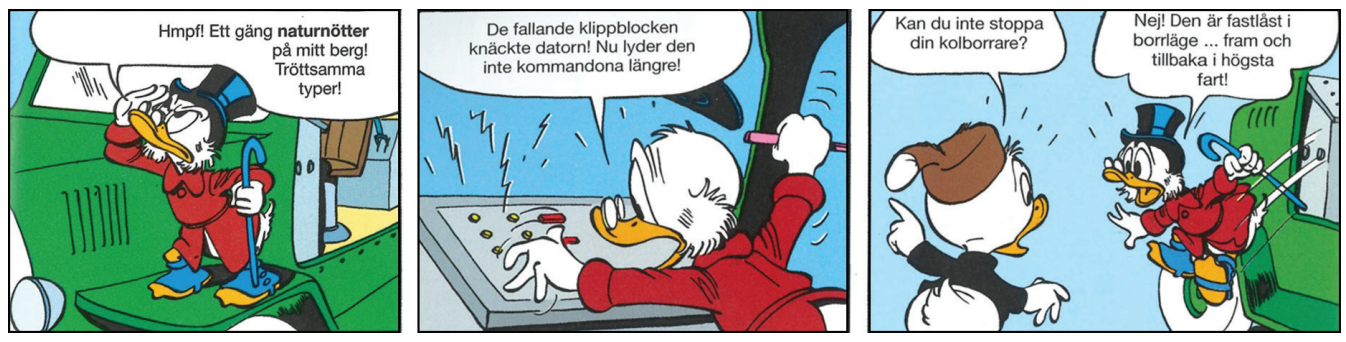

Figur 4. Farbror Joakims skiftande humör, från irritation till oro (Barks \& Jippes, 2013 [1972], s. 53-54, klippt av utrymmesskäl). Reproducerad med tillstånd av Egmont Publishing (C Disney.

Det är alltså skillnad på hur Joakim reagerar på barnens svält i Pengalösa (se nedan) och den direkt livshotande situationen i "Berg i fara" - här kan även tänkas att det påverkar att han är närvarande i den senare sekvensen - och dessutom skyldig till Gröngölingarnas situation - medan barnens utsatthet i Pengalösa är mer fysiskt distanserat.

Detta är en utveckling av karaktären över tid från 50-talets antagonist till vår nutida protagonist (Barrier, 2014), men något som läsare av dessa två seriealbum antagligen inte känner till - vilket kan leda till att Joakims beteende ibland kan verka motsägelsefullt när han används som både antagonist och protagonist. Ur vilket schema ska läsaren förstå Joakim? Det som framkommer i dessa berättelser är att hans girighet kan komma i vägen för det moraliskt riktiga handlandet, men han har sina gränser - och ibland kan hans moral till och med vara vägledande. "Ståtliga statyer" visar att det är bra att inte vara (för) slösaktig. Trots alla Kalles misslyckanden fortsätter Joakim ändå att anställa honom (även om lönen är låg), så han bidrar på det sättet till Kalles uppehälle. Han kan även vara uppmuntrande mot sina släktingar, så länge affärerna lyckas. I "Snålheten bedrar visheten" (Troelstrup \& Santanach, 2012[2006], mer om denna serie nedan) hjälper Kalle till att öka intäkterna för Farbror Joakim, och denne belönar Kalle genom att ge honom mer ansvar och kalla honom "en klippa" (s. 94) - han tar dock en annan ton när allt sedermera går åt skogen. Även om Joakim är en girigbuk och snåljåp i Barks historier, så finns det alltså en komplexitet i hans relation till sina pengar, liksom till sina släktingar, som framkommer genom denna samling av historier.

\section{Den idoga arbetaren och latmasken - värdet av lön för mödan}

I "Pengaregn" följer vi också huvudsakligen Farbror Joakim, Kalle och Knattarna. De arbetar på Joakims bondgård när en cyklon suger upp alla Joakims pengar och sprider dem över landet. Till Kalles stora glädje får han en miljon av dessa och tillsammans med Alexander Lukas ger han sig ut för att se världen. Han upptäcker dock att eftersom 
alla andra i landet (undantaget Joakim och Knattarna) också fått pengar och inte vill arbeta så finns det inte längre någonstans att spendera pengarna. Historien slutar med att Joakims ockerpriser på gården gör att alla tvingas ge tillbaka hans pengar.
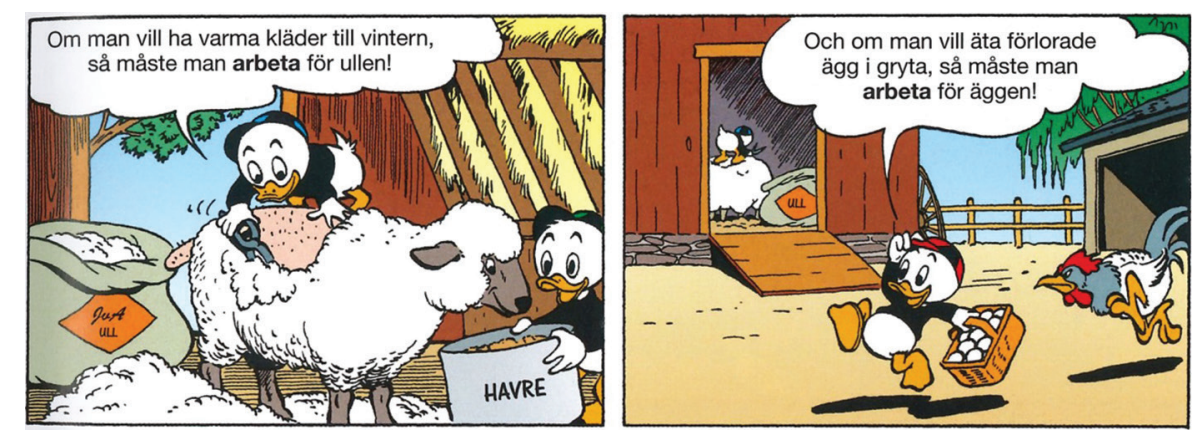

Figur 5. Knattarnas arbetsmoral (Barks, 2013[1951], s. 35). Reproducerad med tillstånd av Egmont Publishing (C) Disney.

Handlingen i serien kretsar runt Kalles avsky för arbete och hans önskan att bli rik. Läsaren kan genom historien associera till schemat att hårt arbete är sin egen belöning, illustrerat framförallt av de idoga, glada Knattarna som gärna arbetar för sitt uppehälle utan att uttrycka någon önskan om rikedom. I figur 5 verbaliserar Knattarna arbetsmoralen, samtidigt som bilderna visar glädjen och fliten som lyser i deras ögon och deras leenden, trots det hårda arbetet. Kalles arbete lönar sig dock sällan, som vana läsare vet: Kalle har alltid varit fattig och fortsätter att vara det, oavsett vilket arbete han företar sig - denna serie börjar och slutar med Kalle i exakt samma position, så inget verkar ha förändrats. Knutsson (1986) menar att denna berättelse visar en "karikerad version av marknadsekonomiens [sic] sätt att fungera" (s. 26): om alla skulle bli rika så skulle alla sluta arbeta, och därför skulle ingen kunna få ett drägligt liv. Bårdsen (2005, s. 32-33) diskuterar den ekonomiska effekten på tre olika ekonomiska agenter, representerade av de olika karaktärerna: Joakim som innehavaren av rikedom, Knattarna som idoga arbetare och Kalle (representant för Ankeborgarna) som en flexibel agent som ändrar sina beteenden beroende på sin ekonomi (en liknande analys görs av Ørvad Andersen et al., 1974). När Kalle blir oförtjänt rik, så slutar han arbeta eftersom hans mål var just att bli rik, vilket i slutändan leder honom i olycka.

Knattarnas syn på det hårda arbetets belöning går i linje med Barks framställning av Joakim som en personifiering av den amerikanska drömmen som arbetat sig till sin förmögenhet (se Barrier, 2014; Ørvad Andersen et al., 1974). Knutsson (1986, s. 27) hävdar att "arbeta med glädje leder till att kapital strömmar in". Dock så stämmer detta inte i Kalles och Knattarnas fall. Tiden i Ankeborg verkar stå still (jfr Ørvad Andersen et al., 1974) och Knattarna idag är inte rikare än de var när Barks historia publicerades (även om de här får 50 öre i löneförhöjning!). Det måste alltså vara det goda arbetet i sig som driver Knattarna - de har roligt när de arbetar. 


\section{Wallner}

Även den rike Joakim arbetar med högaffel i händerna lika hårt som de andra - han är ingen passiv ägare. Joakims omsorg för pengar kommer ifrån det arbete han lagt ner på dem, men det som är speciellt med Joakims relation till sina pengar är att han älskar dem - hur han tycker om att "tumla omkring i dem som en delfin", "gräva [sig] fram genom dem som en mullvad" och "kasta upp dem i luften så de regnar ner över [honom]" (Barks, 2013[1951], s. 37). Barrier (2014) menar att detta relaterar till barns materiella förståelse för pengar, att Joakim har konkreta mynt och sedlar, och att liknelsen till en stor spargris är medvetet utformad (se även Kalka, 2009). Knutsson (1986) visar att mängden guldmynt i Joakims ägo skapar en stark symbol för makt och rikedom. Joakim behandlar sina pengar som både sina leksaker och som vördade minnen, ofta kan han minnas exakt hur han tjänat specifika sedlar och mynt i pengabingen. Värdet på hans pengar är inte instrumentellt utan intrinsikalt (Joakim fnyser åt tanken på att behöva spendera pengar för att andra ska förstå att han är rik) - det är dels den status som pengarna ger honom som världens rikaste anka, den kärlek som han har till det arbete han gör och samlarvärdet som pengarna har för honom - dels den kunskap och erfarenhet som ansamlingen av pengar symboliserar (Knutsson, 1986).

Det finns dock exempel i materialet där Kalle visar mer arbetsiver än i "Pengaregn" - även om det viktiga fortfarande är att bli rik. I "Snålheten bedrar visheten" (Figur 6) lämnar Kalle en treveckors kvällskurs i ekonomi där han lärt sig "lyckas i affärer", med diplom, högt huvud och nedlåtande blick och, som en av hans kurskamrater uttrycker det, "allt man behöver veta för att bli rik" (Troelstrup \& Santanach, 2012 [2006], s. 87-88, betoning i original).

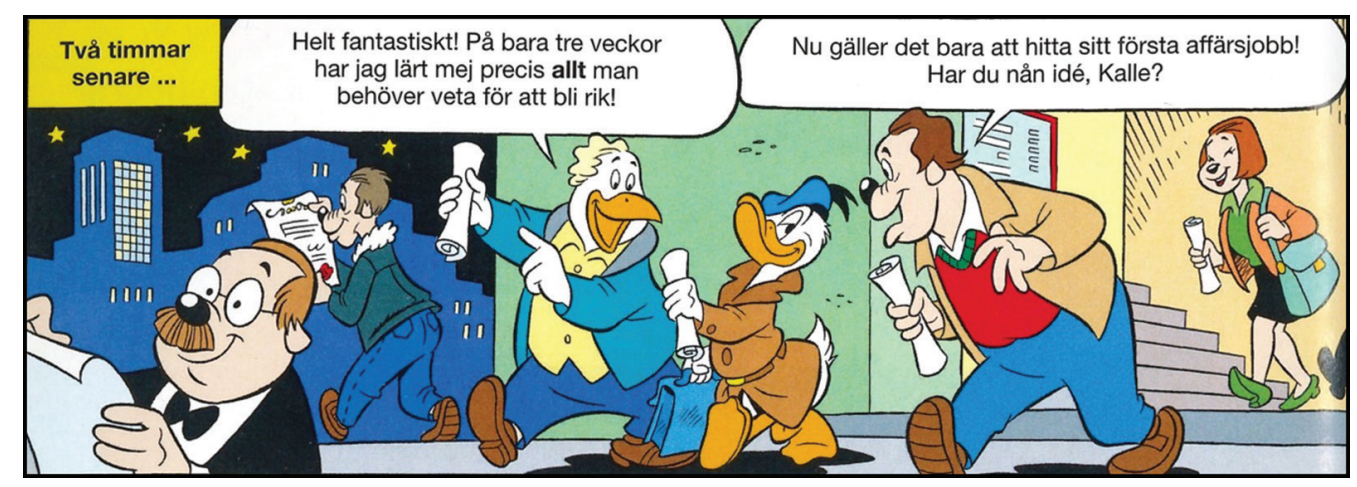

Figur 6. Kvällskursen ger självförtroende i affärer (Troelstrup \& Santanach, 2012 [2006], s. 88).

Reproducerad med tillstånd av Egmont Publishing (C) Disney.

Kalle går genast till Joakim och kräver ett arbete med ansvar. Han får göra en rad förändringar i olika fabriker, framförallt genom att prioritera vinst framför aspekter som säkerhet och kvalitet. Inledningsvis lyckas dessa förändringar få vinsten att öka när produktionskostnaderna går ner, men det slutar med katastrof. Det här är långt ifrån det 
enda exemplet på hur Kalle gärna söker upp arbete i olika former, men hans arrogans, och hans önskan att bli rik snabbt, ställer oftast till det för honom. Han är inte intresserad av att faktiskt lära sig, arbeta hårt och förtjäna pengar som Joakim eller Knattarna.

Schemat som skapas i dessa två berättelser är alltså att den goda arbetsmoralen är sin egen belöning. Knattarnas lycka i att arbeta på gården likställs med Joakims kärlek till sitt arbete och slit under ett långt liv med många äventyr (symboliserat av hans pengasamling). Kalles inställning att han ska bli rik snabbt, helst utan att arbeta, visar läsaren att han är en moraliskt svag karaktär. Hans arbete är ett motvilligt medel för att bli rik snarare än att göra ett gott arbete i sig, vilket gör det omoraliskt. Båda berättelserna "Pengaregn" och "Snålheten bedrar visheten" är cirkulära: I slutet av berättelserna är alla karaktärer tillbaka i samma sits som de började - status quo är återställt - och därmed cementeras också deras ekonomiska lott. Knattarna och Farbror Joakim, som är de karaktärer som varit nöjda med sin plats, och arbetat för nöjet av arbete, är till synes de enda som 'tjänat' på historien, och deras moraliska ställningstagande till arbete är det som framstår som framgångsrikt.

\section{Barn och vuxna - moralisk rikedom och moralisk fattigdom}

Det är inte bara rika i fokus i dessa berättelser. I "Jul i Pengalösa" skildrar Barks fattigdom då Knattarna tar vägen hem genom stadsdelen Pengalösa.
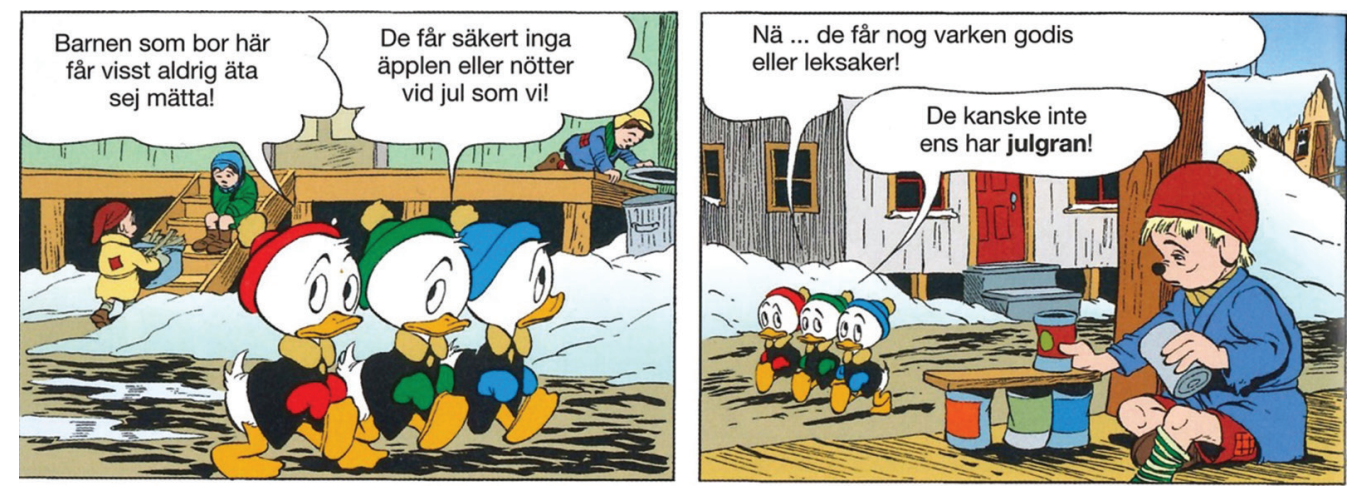

Figur 7. Barnens lidande i Pengalösa (Barks, 2013[1952], s. 68). Reproducerad med tillstånd av Egmont Publishing (C) Disney.

Invånarna i Pengalösa är barn - smutsiga, med fårade ansikten, slitna kläder och plåtburkar som leksaker - vägarna ser ut att inte vara asfalterade och husen är nedgångna (Figur 7). Här använder Barks en realistisk ton i hur han tecknar barnen, i jämförelse med Knattarna som ser än mer tecknade, kritvita och overkliga ut. Knattarna beskriver också i sin dialog hur barnen i Pengalösa lider av fattigdom, i kontrast till hur bra de själva har det. Fattigdomen får här tydliga ansikten, men även andra historier visar representanter för fattigdom, till exempel Björnligan som lever i skjul, med trasiga 


\section{Wallner}

tapeter. Ørvad Andersen et al. (1974) diskuterar bland annat de olika klasskikten inom Kalle Anka och finner Björnligan och de andra vanligast förekommande skurkarna på absoluta botten av samhället, men det är tydligt här att inte bara skurkarna tillhör underklassen.

Här är det återigen Knattarna som är läsarens representanter i texten, och de uppmärksammas på, och sympatiserar mest med, lidandet i Pengalösa. Knattarna blir därmed "mer vuxna än de vuxna" (Barrier, 1973, s. 215) - karaktärer barnläsaren kan se upp till och beundra, ideal att sträva emot. Barnkaraktärer överlag i Disneyserierna representerar "the force which judges and corrects adult errors with adult rationales" (Dorfman \& Mattelart, 1991, s. 46). Dock är det inte bara barnen i dessa två seriealbum som visar goda egenskaper. I "Jul i Pengalösa" uttrycker även Kajsa Anka sympati med barnen, och hennes syförening ordnar en julfest för dem.

Kalle och Joakim får återigen representera omoralen. Även om Kalle vid flera tillfällen uttrycker medlidande så är det snarare som medel för att få Joakims pengar snarare än någon personlig sympati. När han själv måste offra julklappar för barnens skull uttrycker han istället missunnsamhet mot dem: "jag hoppas verkligen att småungarna nere i Pengalösa får glädje av sitt leksakståg!” (Barks, 2013 [1952], s. 75, betoning i original). Farbror Joakim gör i denna historia skäl för sitt engelska förnamn (Scrooge), som engelska läsare associerar till rikedom och omoral. Som i många Barks-berättelser används Joakim här som antagonisten de andra måste manipulera för att få pengar ifrån.

Här kan läsaren förstå att Knattarna, barnen i berättelsen, är de som agerar som ansvarsfulla vuxna för att göra det moraliskt riktiga - medan Kalle och Joakim demonstrerar vuxendomens egoism och girighet. Det schema som skapas här visar läsaren att solidaritet med fattiga och utsatta, genom egna uppoffringar, är gott moraliskt handlande, och Joakims ovilja att ge till de behövande straffar sig i form av att han nästan blir av med sina pengar och slutligen lämnas i sina försök att återfinna dem $i$ slutet på berättelsen. Figur 8 visar kontrasten mellan de glada, kalasande barnen och den sura rikemannen, och i bilden till höger visas även Kalles skadeglädje. Trots sin tidigare egoism finner även Kalle en lycka i ett gott slut för barnen och att Joakim fătt sig en läxa, något som kan spegla läsarens syn på berättelsens moral.



Figur 8. Barnen festar medan Joakim lämnas arg i sin grotta till Kalles skadeglädje (Barks, 2013[1952], s. 99, klippt av utrymmesskäl). Reproducerad med tillstånd av Egmont Publishing (C) Disney. 


\section{Slutord: Vad vi lär oss av Kalle Anka om hårt arbete och pengar}

De texter som diskuterats här följer samma schema: en dikotomi mellan ekonomisk fattigdom och rikedom som i sin tur är sammankopplat med en tudelad syn på moral (hårt arbete är gott, lättja är ont). Herman och Vervaeck (2007) förklarar att narrativ ofta skrivs som dikotomier för att tydliggöra ideologi, och i de analyserade berättelserna finns en tydlig tudelning mellan fattiga och rika, arbete och lättja. Självklart är förenklingar av verkligheten nödvändiga i fiktion för barn (även om vissa av berättelserna, som "Snålheten bedrar visheten", presenterar, för barnläsare, relativt komplicerade ekonomiska koncept). Här är det dock viktigt för läraren, liksom för en vuxen läsare, att problematisera dikotomiseringen som målas upp av de ekonomiska förhållandena i Ankeborg. Vissa av karaktärerna i dessa berättelser skildras som fattiga som en del av sin personlighet (till exempel Kalle) och hur mycket de än må förtjäna rikedom så verkar de sakna kapacitet att få den. Den vuxna läsaren kan se dessa karaktärsdrag och tolka dem ur olika perspektiv - vi kan till exempel förstå det som tecknares och författares sätt att etablera dessa karaktärer och hålla dem 'unga' för olika generationer av läsare - men för en barnläsare finns en risk att karaktärsdragen blir fasta kognitiva scheman för hur hen ska förstå världen och människor runt omkring sig.

Farbror Joakim använder ofta sina pengar för att ta med Kalle och Knattarna ut på äventyr för att hitta skatter (Barrier, 2014), och Joakims förmögenhet blir på så sätt en positiv kraft för att få ut ankorna på nya äventyr. Rikedom illustreras som något eftersträvansvärt så länge den åstadkoms genom hårt arbete (som Joakim gjort), och inte genom omoraliskt beteende. Detta kan sägas fostra barnläsaren i en etik om hårt arbete och lön för mödan (som Knattarna). Dock så inkluderar berättelserna i dessa två samlingar inte dessa äventyr som kan visa hur Joakims pengar används för att göra gott, så genom dessa samlingar är det svårt att argumentera för detta. Samtidigt är bilden av svaga och utsatta i serierna problematisk i en skola som förväntas fostra elever med en värdegrund byggd på "solidaritet mellan människor" (Skolverket, 2019 , s. 5). Om fattigdomen är intrinsikal i vissa personer finns det en risk att solidariteten ses som meningslös. I serierna visas också samhällets förväntningar på välgörenhet från den som har pengar: välgörenhet illustreras som godhjärtat, men när pengarna tas i form av skatter framställs det istället som utsugande (framförallt ur Joakims perspektiv, men även från Kalle och andra 'hårt arbetande' karaktärer).

I Kalle Anka görs fostrandet inte på samma sätt som i till exempel Bamse, eller pedagogiska serier, där det undervisande perspektivet är mer explicit (se till exempel Magnusson, 2005). I Kalle Anka måste läsaren själv problematisera de associationer som kan göras i och mellan panelerna - här kan läraren, eller en annan vuxen, agera som filter för att kunna bena ut komplicerade begrepp och perspektiv. De perspektiv som lyfts här skulle vara intressanta att sätta i relation till en vidare serievärld - hur till exempel Bamse-redaktionen hanterar frågor om pengar, eller andra serier riktade till andra åldersgrupper av läsare. 


\section{Wallner}

Knattarna används här som "surrogat för barn-läsaren" (Barrier, 2014, s. 309), där de tre pojkarna får representera det kompetenta barnets perspektiv. Kåreland (2009, s. 25) skriver att "[d] et kompetenta barnet bör ... ses i relation till synen på och skildringen av föräldrarna". Då Joakim och Kalle inte är (biologiska) föräldrar, så kan de också slippa undan en del av det ansvar som föräldrar skulle kunna krävas på av läsaren. I dessa berättelser blir däremot Joakims snikenhet och Kalles lathet två moraliskt negativa förebilder att ställas i relation till Knattarnas positiva egenskaper av generositet och arbetsiver (jfr Lindgren, 2000), för att visa på förebilder för läsaren i förhållande till pengar.

Knutsson (1986) visar hur Kalle Anka-serierna kan förstås som något mer än krass kommersialism och ideologipredikan. Här finns budskap och värden som både barn och vuxna kan lära sig av, något som också är synligt i de texter som undersökts här. Serier fungerar som både estetisk upplevelse och pedagogiskt redskap, där Farbror Joakims förmögenhet och Kalles slit ger barn både "näring åt drömmar" (Kåreland, 2009, s. 36) och samtidigt en realistisk bild av det hårda arbetets dygd, som kan krävas för att nå denna dröm. Det är möjligt att betrakta Knattarnas arbetsiver som ett medel för att nå Joakims nivå av rikedom och ett förhärligande av ett kapitalistiskt system (Ørvad Andersen et al., 1974), men samtidigt står tiden stilla i Kalle Anka, vilket skulle innebära att även Knattarnas strävan mot rikedom i slutändan skulle vara fruktlös i likhet med Kalles drömmar om rikedom. Då är det istället mer fruktbart att se Knattarna som exempel på hur arbete är sin egen intrinsikala belöning.

\section{Författarpresentation}

Lars Wallner är universitetslektor vid Linköpings universitet i pedagogiskt arbete. Hans doktorsavhandling undersöker användning av serietidningar i klassrummet, och hans forskningsintressen berör utbildning, social interaktion och litteratur.

\section{Referenser}

Barks, C. (2012[1952]). Ståtliga Statyer. I D. Carlsson (Red.), Välkommen till Ankeborg, s. 76-85. Översatt av A. Norbeck. Malmö: Egmont Kärnan.

Barks, C. (2013[1951]). Pengaregn. I D. Carlsson (Red.), Kalle Anka och hans vänner, s. 35-44. Översatt av A. Norbeck. Malmö: Egmont Kids Media.

Barks, C. (2013[1952]). Jul i Pengalösa. I D. Carlsson (Red.), Kalle Anka och hans vänner, s. 68-99. Översatt av A. Norbeck. Malmö: Egmont Kids Media.

Barks, C. \& Jippes, D. (2013[1972]). Berg i fara. I D. Carlsson (Red.), Kalle Anka och hans vänner, s. 45-57. Översatt av S. Diös. Malmö: Egmont Kids Media.

Barrier, M. (1973). The Duck Man. In D. Thompson \& D. Lupoff (Eds.), The Comic-Book Book, p. $207-225$. New Rochelle: Arlington House.

Barrier, M. (2014). Funnybooks: The Improbably Glories of the Best American Comic Books. Oakland: University of California Press.

Belk, R. W. (1987). Material Values in the Comics: A Content Analysis of Comic Books Featuring Themes of Wealth. Fournal of Consumer Research, 14, 26-42.

Bordwell, D. (1991). Making Meaning: Inference and Rhetoric in the Interpretation of Cinema. Harvard University Press.

Bårdsen, G. (2005). Carl Barks: Ein Klassisk Økonom? Økonomisk Forum, 59(1), 31-36. 
Carlsson, D. (Red.). (2012). Välkommen till Ankeborg. Malmö: Egmont Kärnan.

Carlsson, D. (Red.). (2013). Kalle Anka och hans vänner. Malmö: Egmont Kids Media.

Dorfman, A. \& Mattelart, A. (1991). How to Read Donald Duck: Imperialist Ideology in the Disney Comic (4th ed.). New York: I.G. Editions, Inc.

Egmont Publishing. (2019a). Kalle Anka i skolan. Malmö: Egmont Publishing. Hämtad 12 februari, 2020, från http://serieriundervisningen.se/kalle-anka-material/

Egmont Publishing. (2019b). Serier $i$ Undervisningen (Om Oss). Malmö: Egmont Publishing. Hämtad 12 februari, 2020, från http:/www.serieriundervisningen.se/om-oss/

Frow, J. (2018). Character. In M. Garrett (Ed.), The Cambridge Companion to Narrative Theory, p. $105-119$. Cambridge: Cambridge University Press.

Herman, L. \& Vervaeck, B. (2007). Ideology. In D. Herman (Ed.), The Cambridge Companion to Narrative, p. 217-230. Cambridge: Cambridge University Press.

Kalka, J. (2009). Money as We Knew It? New Left Review, 60, 65-76.

Kintsch, W. (1998). Comprehension: A Paradigm for Cognition. Cambridge: Cambridge University Press.

Knutsson, M. (1986). Kalle Anka, Karl Marx och Carl Barks - Två sätt att läsa fabeldjurserier. Barnboken, 9(2), 22-29.

Knutsson, M. (2018). Moralpanik - serier i moralens värld. Bild E̋ Bubbla, 217, 91-96.

Kukkonen, K. (2013). Contemporary Comics Storytelling. Lincoln: University of Nebraska Press.

Kåreland, L. (2009). Barnboken i samhället. Lund: Studentlitteratur.

Lindgren, A.-L. (2000). Kalle Anka: En progressiv barnuppfostrare. Tvärsnitt - Humanistisk och samhällsvetenskaplig forskning, 4, 32-37.

Magnusson, H. (2005). Berättande bilder. Svenska tecknade serier för barn. Göteborg \& Stockholm: Makadam.

Nikolajeva, M. (2017). Barnbokens byggklossar (3. uppl.). Lund: Studentlitteratur.

Skolverket. (2017). PIRLS 2016: Läsförmågan hos svenska elever i årskurs 4 i ett internationellt perspektiv. Stockholm: Skolverket. Från https://www.skolverket.se/download/18.6bfaca41169863e6a65cf05/ 1553967689286/pdf3868.pdf

Skolverket. (2019). Läroplan för grundskolan, förskoleklassen och fritidshemmet 2011 (6. rev. uppl.). Stockholm: Wolters Kluwer. Hämtad 20 augusti, 2019 från Skolverket, https://www.skolverket.se/publikationer?id=4206

Sparrman, A. \& Sandin, B. (2012). Situated Child Consumption - an Introduction. In A. Sparrman, B. Sandin \& J. Sjöberg (Eds.), Situating Child Consumption - Rethinking Values and Notions of Children, Childhood and Consumption, p. 9-31. Lund: Nordic Academic Press.

Tilley, C. L. \& Weiner, R. G. (2017). Teaching and Learning with Comics. In F. Bramlett, R. T. Cook \& A. Meskin (Eds.), The Routledge Companion to Comics, p. 358-366. New York \& London, Routledge.

Troelstrup, S. (manus) \& Santanach, T. (teckningar). (2012[2006]). Snålheten bedrar visheten. I D. Carlsson (Red.), Välkommen till Ankeborg, s. 87-96. Översatt av S. Diös. Malmö: Egmont Kärnan.

Wallner, L. (2017). Framing Education: Doing Comics Literacy in the Classroom (Doktorsavhandling). Institutionen för samhälls- och välfärdsstudier, Linköping: Linköpings universitet.

Woolgar, S. (2012). Ontological Child Consumption. In A. Sparrman, B. Sandin \& J. Sjöberg (Eds.), Situating Child Consumption - Rethinking Values and Notions of Children, Childhood and Consumption, p. 33-51. Lund: Nordic Academic Press.

Ørvad Andersen, L. et al. (1974). Tegneserier: en ekspansions historie (3. uppl.). Grenå: GMT. 